\title{
Bioseguridad en el personal de salud en tiempos de pandemia
}

os coronavirus son una amplia familia de virus que puede causar diversas afecciones; como fiebre, tos y dificultad para respirar, en los casos más graves neumonía, síndrome respiratorio agudo severo e insuficiencia renal (1).

La pandemia por Covid-19, ha originado una emergencia sanitaria que ha requerido acción inmediata de los gobiernos, las empresas y las personas. Esta situación epidemiológica ha superado la capacidad de respuesta de los hospitales y personal de salud; enfermeras, médicos, entre otros que están en primera línea de atención, considerada como área de muy alto riesgo de exposición a contacto directo; en el cual se realizan procedimientos generadores de aerosoles como entubación, de inducción de tos, broncoscopias; que generan micropartículas respirables e inhalables menores a 10 micras que permanecen esparcidas en el ambiente, generando inóculos infectantes de transmisión de pacientes a profesionales de la salud. En este contexto hay miles de contagios y cientos de muertes del personal de salud: enfermeras y médicos; por tanto es urgente adoptar medidas; capacitar en la prevención y el control de las infecciones y actualizar esas competencias periódicamente, así también en áreas Covid-19; deben vigilarse los controles de ingeniería; el mantenimiento preventivo y correctivo del aire, de cubículos de aislamiento y seguimiento administrativo de sanitización y descontaminación de las áreas; la dotación de insumos, así como la vigilancia periódica de la salud del personal expuesto, las normas, protocolos de bioseguridad; el uso obligatorio del equipo de protección personal que sea ergonómico y seguro, de alta eficiencia; googles y escudos o mascaras faciales anti niebla, resistentes a ralladuras y químicos; fáciles de limpiar y desinfectar, guantes de nitrilo con sensibilidad táctil, resistentes a desgarro; batas y overol tipo tyvek desechable que cubren todo el cuerpo, impermeable para aislar de los líquidos corporales que contengan agentes patógenos y evitar el contacto directo con el paciente potencialmente infectado, y las botas impermeables antiderrapantes desechables (2).

En la protección respiratoria como principal vía de entrada del coronavirus; Las mascarillas respiradoras de presión positiva o negativa que purifican o suministra aire, protegen al usuario contra contaminantes que se encuentran en el medio ambiente laboral, se designan de acuerdo con su tipo y nivel de eficiencia de filtrado, conforme se indica a continuación:

- Nivel mínimo de eficiencia del 99.97 por ciento, filtros N 100, R 100 y P 100.

- Nivel mínimo de eficiencia del 95 por ciento, filtros N 95, R 95 y P 95.

- Nivel mínimo de eficiencia del 90 por ciento, filtros N 90, R 90 y P 90.

Donde " $N$ " significa No resistente al aceite; " $R$ " relativamente Resistente al aceite; y " $P$ " muy resistente a Prueba de aceite; varios de estos equipos cuentan con una válvula de exhalación que facilita la respiración y ayuda a disipar el calor, la humedad y el $\mathrm{CO}_{2}{ }^{(3)}$, para seguridad del usuario se recomienda la verificación del ajuste considerando tres elementos: sellado, estabilidad y compatibilidad. La mascarilla debe quedar perfectamente sellada con la piel; es indispensable y recomendable no usar maquillaje, barba o bigote que impida el sellado y estabilidad, debe ser compatible con el resto de equipo de protección personal que pudiese interferir con el sellado como de googles, caretas, entre otros. Es importante respetar las instrucciones del proveedor para su máxima efectividad y evitar en riesgo de contagio. 
El personal de enfermería es una pieza clave en el funcionamiento de un hospital; Es necesario invertir, valorar y empoderar a la enfermería; fomentar el valor social como trabajadores de la salud, capacitar y sensibilizar sobre cuidado propio y bioseguridad, valorar la vida propia ante una profesión de alto riesgo; luchar por la regulación y las condiciones laborales para un trabajo digno y salario justo, para los profesionistas que exponen su vida en el cuidado de la salud de otros.

\author{
Dra. en Edu.P. Miriam Gómez Ortega \\ Profesora Investigadora de Tiempo Completo \\ Universidad Autónoma del Estado de México \\ Facultad de Enfermería y Obstetricia \\ mgomezo@uaemex.mx
}

\title{
REFERENCIAS BIBLIOGRÁFICAS
}

1. Coronavirus [en línea]. Organización Panamericana de la Salud (OPS); 2020 [Acceso 21 de abril de 2020]Disponible en: https://www.paho.org/es/temas/coronavirus

2. Guía sobre la preparación de los lugares de trabajo para el virus Covid-19 Administración de Seguridad y Salud Ocupacional (OSHA) USA. (2020). [Acceso 28 de mayo de 2020]Disponible en: www.osha.gov

3. Seguridad equipo de protección personal respiradores purificadores de aire de presión negativa contra partículas nocivas especificaciones y métodos de prueba. NOM-116-STPS 2009: SEGOB (2009) Acceso 26 de mayo de 2020] Disponible en: http://www.dof.gob.mx/normasOficiales/3926/stps3/stps3.htm

Copyright $\odot 2020$ SANUS

Artículo de acceso libre distribuido

bajo licencia Creative Commons

\section{(c) $19 \Theta$

\section{Cómo citar este artículo}

Gómez-Ortega M. Bioseguridad en el personal de salud en tiempos de pandemia. SANUS. 2020; (14):1-2.[Acceso_- _- _ ] ]; Disponible en:__ 